expect much greater $\mathrm{X}$-ray emission accompanying a flare capable of producing an S.I.J.

We hope to obtain the experimental measurements needed to answer the question of the relative importance of Lyman $\alpha$-and X-rays in S.I.D. phenomena from a series of rockets to be fired during the International Geophysical Year. Beginning July I, fourteen Nike-Deacon rockets instrumented to measure Lyman $\alpha$-and $\mathrm{X}$-rays will be ready for firing from San Nicolas Is. in the Pacific Ocean off Point Mugu, California. These rockets will be held in readiness for the occurrence of flares producing S.I.D. Combined with the flare observations on Mt. Wilson, Sacramento Peak and Climax, these measurements should contribute substantially to our understanding of solar flares.
T. A. ChubB
H. FrIEDMaN
R. A. KREPLIN
J. E. KUPPERIAN, JUN.

U.S. Naval Research Laboratory,

Washington 25, D.C.

${ }^{1}$ Waynick, A. H., Proc. Inst. Rad. Eng., 45, 711 (1957).

\section{Chemical Mechanism of Permanent Set}

AlL available methods of imparting a permanent set to strained wool fibres are based on two consecutive intramolecular reactions, namely, disulphide bond breakdown, which promotes relaxation, and linkage rebuilding, which fixes the relaxed structure in its deformed state. The linkage rebuilding reactions are complex ${ }^{1}$, but when a boiling 2 per cent solution of borax is used as the setting agent, one important reaction is that between the sulphenic acid, formed by breakdown of the disulphide bond, and the basic side-chains; set fibres contain fewer free lysine sidechains than untreated fibres ${ }^{2}$, and fibres treated with 1-fluoro-2:4-dinitrobenzene acquire much less set than untreated fibres ${ }^{3}$. In striking contrast with these observations, it has now been found that the lysine side-chains play little, if any, part in the setting of strained fibres in a boiling solution of sodium bisulphite.

Lincoln wool fibres in the untreated state, after treatment with buffer and after treatment with 1-fluoro-2:4-dinitrobenzyl, were stretched 35 per cent, boiled for $30 \mathrm{~min}$. in either a 2 per cent solution of borax or a 5 per cent solution of sodium bisulphite, and then released in boiling water. The amounts of set retained by the fibres after various times of release are shown in Table 1. Fibres treated with 1 -fluoro-2 : 4-dinitrobenzene show such a marked contrast between borax and sodium bisulphite as setting agents as to leave no doubt that the main linkage-rebuilding reaction is different in the two

Table 1

\begin{tabular}{|c|c|c|c|c|}
\hline \multirow{3}{*}{$\begin{array}{l}\text { Setting agent } \\
\text { Borax }\end{array}$} & \multirow{3}{*}{$\begin{array}{l}\text { Treatment of fibre } \\
\left\{\begin{array}{l}\text { Untreated } \\
\begin{array}{l}\text { Buffer } \\
1-\text { Fluoro-2: } 4 \text {-di- } \\
\text { nitrobenzene }\end{array}\end{array}\right.\end{array}$} & \multicolumn{3}{|c|}{$\begin{array}{l}\text { Percentage set after re- } \\
\text { lease in boiling water for: } \\
5 \mathrm{~min} .30 \mathrm{~min} \text {. } 60 \mathrm{~min} \text {. }\end{array}$} \\
\hline & & $\begin{array}{l}28 \cdot 3 \\
24 \cdot 1\end{array}$ & $\begin{array}{l}26 \cdot 6 \\
22 \cdot 0\end{array}$ & $\begin{array}{l}26 \cdot 3 \\
21 \cdot 4\end{array}$ \\
\hline & & $18 \cdot 6$ & $12 \cdot 8$ & $11 \cdot 9$ \\
\hline \multirow{2}{*}{ Sod. bisulphite } & \multirow{2}{*}{$\begin{array}{l}\text { Untreated } \\
\text { Buffer } \\
\text { 1-Fluoro-2 : 4-di- } \\
\text { nitrobenzene }\end{array}$} & $21 \cdot 7$ & $21 \cdot 2$ & $21 \cdot 1$ \\
\hline & & & & \\
\hline
\end{tabular}

cases. This deduction is supported by the fact that there is little difference between the amounts of free lysine side-chains in untreated wool and wool which has been set at 40 per cent extension in a boiling 1 per cent solution of sodium bisulphite for $1 \mathrm{hr}$. The set fibres were treated with 1 -fluoro- $2: 4$-dinitrobenzene and then hydrolysed, the $\varepsilon-N$-dinitrophenyllysine being isolated from the hydrolysate and estimated colorimetrically ${ }^{2}$. The lysine content of the set fibres was found to be $3 \cdot 44$ per cent, compared with 3.38 per cent for the untreated wool. In the light of these and earlier results ${ }^{1}$, it seems clear that the rebuilding of disulphide bonds is the main crosslinking reaction when stretched wool fibres are set by means of a boiling solution of sodium bisulphite.

R. S. Asquith

J. B. Speak MaN

E. TøLGYESI

Textile Chemistry Laboratory,

Department of Textile Industries, University, Leeds.

$$
\text { June } 4 .
$$

${ }^{1}$ Speaknian, J. B., and Stoves, J. L., J. Soc. Dyers and Colourists, 53, 236 (1937)

${ }^{2}$ Asquith, R. L., and Speakman, J. B., Proc. Int. Wool Text. Res. Conf., Vol. C., Pt. 2, 302 (1955).

${ }^{3}$ Farnworth, A. J., and Speakman, J. B., Tature, 161, 890 (1948).

\section{An Approach to the Synthesis of Polycyclic Peptides}

According to the cyclol hypothesis of peptide structure ${ }^{1,2}$, intact peptides may have polycyclic structures which can be visualized, in part at least, as polycyclizations of peptide chains by means of $[\mathrm{CO}, \mathrm{HN}$ to $\mathrm{C}(\mathrm{OH})-\mathrm{N}]$ proton transfers. Here the $\mathrm{H}$ of the $\mathrm{NH}$ group of one residue is transferred to the CO-group of another: a N-C bond forms and the CO-group is replaced by a tertiary carbinol ${ }^{3}$. There result multiple as well as the $\mathrm{CO}-\mathrm{NH}$ single peptide groupings. Fig. I shows some structures which emerge when consideration is confined to $(1,6)$ and $(3,7)$ transfers and piperazine and hydantoin rings are formed.

A molecule containing a multiple peptide or cyclol grouping has been synthesized ${ }^{4}$, following the discovery of such a grouping in the peptide moiety of the ergot alkaloids ${ }^{3}$. This communication is concerned with the possible presence of such groupings in other synthetic molecules ${ }^{5-8}$.

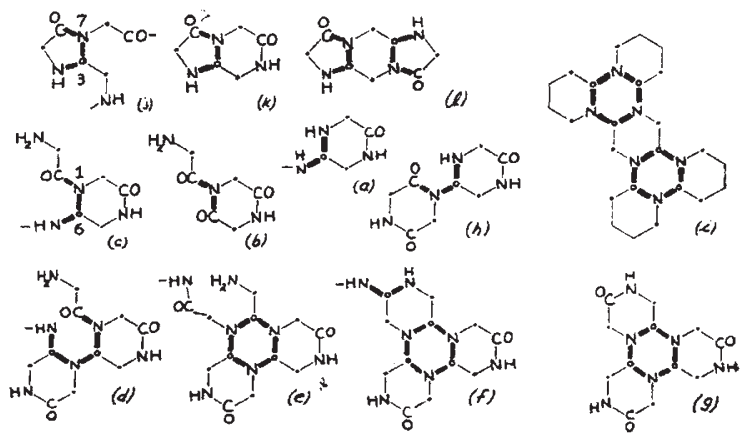

Fig. 1. Cyclized peptide chains, open and closed, in which . denotes $C H R$ and o denotes $C^{*}(O H)$, and multiple peptide groupings composed of $2-, 3-, 6$-bonds uniting the residues are marked by heavy lines. Polycyclizations leading to cyclol- 6 are depicted in $(c-g)$, the structure cyclol-10 in $(i)$. The diagrams indicate that hydrogen bridges would be possible in most cases, and that water molecules may be built in by means of hydrogen
bridges, particularly in (i) 